\title{
Motivation to Teach: A Mixed Method Study
}

\author{
Suzan Canl1* \\ Educational Sciences, Niğde Ömer Halisdemir University, Niğge, Turkey \\ ORCID: 0000-0003-3619-3345
}

\author{
Nülifer Karadă \\ Adlyaman Mimar Sinan Vocational and Technical Anatolian High School, Adlyaman, Turkey \\ ORCID: 0000-0001-8431-9104
}

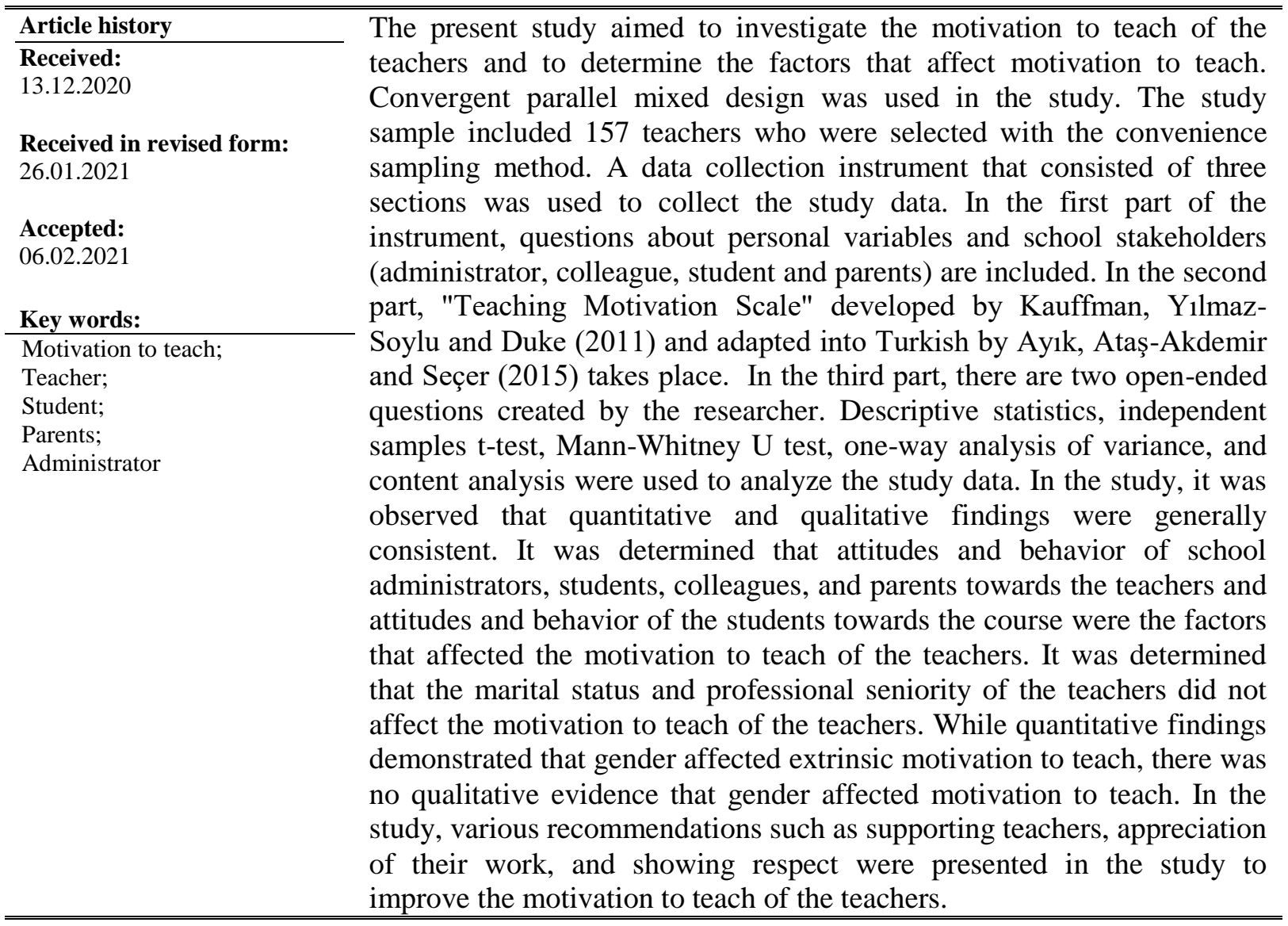

\section{Introduction}

The concept of motivation, derived from the word "movere," to mobilize in Latin (Dörnyei \& Ushioda, 2011; Tanrı̈̈̆gen, 2018), is described as a driving force (Dobre, 2013) or energy that mobilizes individuals to meet an unsatisfied need or achieve a specific goal (Han

\footnotetext{
*Correspondency: canlisuzan@gmail.com
} 
\& Yin, 2016). Motivation is the development of a situation or a situation that includes all factors that determine the degree of willingness to participate in any activity based on another description (Evans, 1998). Thus, the motivation that attempts to explain the behavior of individuals and their efforts in various activities (Watters \& Ginns, 2000), is associated with the direction and magnitude of human behavior (Dörnyei \& Ushioda, 2011) and an individual who does not feel a driving force or inspiration to conduct a particular behavior is considered without motivation, while those who do are considered as motivated (Ryan \& Deci, 2000).

The common denominator of the motivation theories is what motivates individuals to make specific choices, take action, make an effort, and maintain their acts (Dörnyei \& Ushioda, 2011). Motivation has a complex psychological structure (Watters \& Ginns, 2000). Czubaj (1996) argued that the focus on control is an underlying factor in motivation and individuals behave based on internal and external control foci. According to Ryan and Deci (2000), intrinsic and extrinsic motivation should be analyzed separately based on the factors that induce a behavior. Intrinsic motivation is based on the individual's internal needs (Akbaba, 2006) and controlled by the individual (Yazic1, 2009). Thus, the source of intrinsic motivation is the individual (Tanriöğen, 2018). Intrinsic motivation includes impulses that depend on the perceptions, values and beliefs of individuals, and direct the individual to initiate and maintain a behavior (Sinclair, 2008). The curiosity of the individual, the desire for sufficiency and self-improvement, and alike are intrinsic motivation factors (Akbaba, 2006). The intrinsic motivation drives include personal interest, self-satisfaction, or altruism (Sinclair, 2008). When such individuals consider their tasks meaningful and complete these tasks, they are satisfied with these tasks (Tanriöğen, 2018). These individuals voluntarily perform acts and do not need any external incentives. Thus, they perform the act for fun and not for an external urge, pressure, or reward. The fact that the task is interesting and enjoyable leads them to act (Ryan \& Deci, 2000). Extrinsic motivation stems from other individuals and conditions (Sinclair, 2008). Thereupon, it is based on external causes (Ryan \& Deci, 2000) and controlled by the environment (Yazic1, 2009). Factors such as wage, promotion, and appreciation based on the performance of the individual increase extrinsic motivation (Ertürk, 2016). For example, selection of the teaching profession due to the salary, working conditions, or the ideals of others that they should be teachers are extrinsic motivation factors (Sinclair, 2008).

It is generally assumed that motivation positively affects the behavior and performance of the individual at work (Ofoegbu, 2004). The requirements of job satisfaction of the employees and their motivation to fulfill the assigned tasks and organizational goals (Dobre, 2013) for the success of the organization increase the significance of motivation. In education, motivation is considered as an important factor for an active learning and instruction process (Akbaba, 2006). A strong climate is present in classes where teachers and students have high motivation levels. In addition, educational activities are not considered as difficult or boring, teachers and students work harmoniously and energetically in collaboration (McInerney \& Liem, 2008). Thus, motivation, one of the most popular topics in the fields of psychology and education (Han \& Yin, 2016), should be prioritized in effective education and instruction.

Several studies were conducted on students' learning motivation. However, fewer studies were conducted on teacher motivation (Retelsdorf, Butler, Streblow \& Schiefele, 2010; Webb $\&$ Ashton, 1986). Studies on teacher motivation were introduced in the late 1990s. In recent years, it was observed that teacher motivation was investigated and prioritized in several sociocultural studies (Han \& Yin, 2016). There indeed are certain factors behind the significance of teacher motivation. For example, according to Czubaj (1996), the emotions of 
the teacher affect the emotions of the students. If the teacher does not like teaching, it is highly likely that the students do not like the education they get. However, when the teacher loves the job, students love the education they receive. One of the factors that allow the teacher to love the profession is reported as motivation in a fair number of studies. According to Ofoegbu (2004), teacher motivation is an essential factor for a class activity and school development. Davidson (2007) reported that several facilities could be available such as additional resources, increasing the quality of teachers, providing tools and materials, and so on for active education and instruction; however, none of these facilities could ensure that teachers would fulfill their duties as desired. Teachers need to be motivated to perform their duties effectively. According to Özdemir, Kartal, and Yirci (2014), teacher motivation is important to achieve academic goals, create an active learning environment, a peaceful job environment, a positive school culture, sincere teacher attitudes towards their duties, and their commitment to the profession and the school.

Since teachers are the most important factor in the education of future generations, they should use their abilities to the fullest and perform their best. Furthermore, teacher performance is considered to be a factor that affects student performance. Thus, teacher motivation should be considered as a factor that affects teacher performance (Iliya \& Ifeoma, 2015). In fact, previous research on teacher motivation demonstrated that it was closely associated with several educational variables such as student motivation, education reform, instruction practices, and psychological satisfaction of the teachers (Han \& Yin, 2016). For example, according to Ofoegbu (2004), teacher motivation is associated with teachers' attitudes towards work, their desire to participate in pedagogical processes at the school, the interest of the students in class discipline, and student control. Thus, teacher motivation affects the participation of teachers in academic or non-academic activities at school. Barbieri, Rossetti, and Sestito (2017) reported that teacher motivation positively affected student achievements as well. According to Atkinson (2000), there was a positive correlation between teacher and student motivation. Akman (2017) reported a positive correlation between teachers' professional motivation and organizational identification, and professional motivation predicted organizational identification. According to Yllmaz (2014), there was a positive correlation between the motivation levels and the job satisfaction of the teachers. Thusly, teacher motivation is required to perform their duties effectively (Webb \& Ashton, 1986). However, it should be noted that different individuals act based on different reasons; thus, different strategies should be employed when motivating different individuals. Namely, while a particular employee could be motivated by a higher salary, another could be motivated by a better working environment (Dobre, 2013). Therefore, the factor that motivates a particular individual the most should be determined.

The motivations of teachers are analyzed with different methods based on motivation factors, job motivation, professional motivation, and motivation to teach that lead them to conduct the profession of teaching. For example, interest in instruction, the desire to teach, love for children, desire to work with children or adolescents, care for children, acting for the benefit of children, sacrifice, the idea that teaching others is valuable, the idea that it is important to make a difference in the lives of others, the desire to help others, love for learning and teaching, the desire to inform, the influence of family members or previous teachers, work hours, working conditions, salary, career security, holidays, work schedule, the nature of the teaching profession are among the motivational factors that lead individuals to become teachers (Sinclair, 2008). Personal conditions and administrative, systemic, parental, academic, student, and colleague factors affect the professional motivation of the teachers (Ertürk \& Aydın, 2017). Teachers' motivation to teach is the motivation for the act of 
instruction and could be influenced by several variables such as school administration, parents, students, education-instruction environment, and the general and professional proficiency of the teacher (Argon \& Cicioğlu, 2017). Studies have shown that teaching motivation is related to teachers' self-efficacy level (Avc1, 2019), child-loving level (İl̆gan, Canoğlu, Karamert, \& Şensoy, 2018), job satisfaction, job performance, working conditions (Amin, 2015) and teaching method (student-centered and teacher-centered teaching method) (Alimohammadi, Sohrabi, \& Saberi, 2017). More research to be held is required when the importance of teaching motivation for the effectiveness of teaching is taken into account, which is the main task of teachers. On the other hand, it is difficult for a teacher who does not like to teach, does not want to teach, to teach students. In this respect, teachers should have a high level of motivation to teach. However, it was determined in several different studies that teachers' teaching motivation levels tended to be medium (Altay, 2019; İlgan et al., 2018) and low (Argon \& Cicioğlu, 2017). In this case, conditions that increase teachers' motivation to teach ought to be created. This can be possible by determining the factors that affect teachers' teaching motivation. Determining these factors can provide guidance in creating the necessary conditions for teachers to have the desired level of teaching motivation.

\section{The aim of the study}

The present study aimed to investigate the motivation to teach of the teachers and to determine the factors that affect motivation to teach. For this purpose, the following research questions were determined:

(1) What is the level of teachers' perceptions of the motivation to teach?

(2) Is there a significant difference in terms of their gender in teachers' perceptions of the motivation to teach?

(3) Is there a significant difference in terms of their marital status in teachers' perceptions of the motivation to teach?

(4) Is there a significant difference in terms of their professional seniority in teachers' perceptions of the motivation to teach?

(5) Are gender, marital status, and professional seniority significant factors that affect teachers' perceptions of the motivation to teach?

(6) Is there a significant difference in teachers' perceptions of the motivation to teach based on their satisfaction with the attitudes and behavior of school administrators towards the teachers?

(7) Is there a significant difference in teachers' perceptions of the motivation to teach based on their satisfaction with the attitudes and behavior of colleagues towards the teachers?

(8) Is there a significant difference in teachers' perceptions of the motivation to teach based on their satisfaction with the attitudes and behavior of students towards the course?

(9) Is there a significant difference in teachers' perceptions of the motivation to teach based on their satisfaction with the attitudes and behavior of students towards the teachers?

(10) How do the attitudes and behaviors of school administrators, colleagues, students, and parents towards the teachers influence the motivation to teach of teachers?

(11) How do the attitudes and behaviors of students towards the course influence the motivation to teach of teachers? 


\section{Method}

\section{Design}

In the present study, the converging parallel mixed design was employed. The reason for choosing this design is to collect different but complementary data on teachers' motivation to teach, and to compare quantitative results with qualitative findings to support and validate the results (Creswell and Plano Clark, 2015). In this design, quantitative and qualitative data are collected concurrently, analyzed individually, and then the findings are combined in the interpretation stage to determine whether the collected data are in agreement (Creswell, 2014). In other words, quantitative and qualitative findings are presented individually, compared based on similarities and contradictions in the discussion and conclusion sections, and interpreted with a holistic approach (Şad \& Şahiner, 2016). Thus, the factors that affect the motivation to teach of the teachers could be better understood by the determination of the similarities between the quantitative and qualitative data and whether they support one another. Several factors that affected the motivation to teach of the teachers were analyzed and the data were compared with triangulation in the present study (Katıtaş, 2019). The factors that could affect the motivation to teach of the teachers were analyzed both quantitatively and qualitatively. In the study, quantitative data were used to answer subproblems among 1-9. Qualitative data were used to answer the 10th and 11th sub-problems.

\section{Population and sample}

As teacher branch is a variable that affects teachers' motivation to teach (Avc1, 2019) teaching motivation may be affected by some factors that may be specific to the branch. In this respect, it is thought that it would be more beneficial to examine teachers' teaching motivations on the basis of branch. This research was carried out with Turkish Language and Literature teachers. Turkish Language and Literature is important for students' diploma grades as it is a compulsory and required course, which is taught to all secondary school students (all students in mathematics and science strand, social sciences and literature strand, mathematics and social sciences strand) 5 hours per week. In addition, this course is important for exam success as the university entrance exam includes questions based on the course content. To this end, effective teaching of this course is required.

The study population included Turkish Language and Literature teachers employed in public middle schools in the province of Adiyaman in Turkey. In studies using convergent parallel mixed design, samples in quantitative and qualitative parts may consist of the same or different people. If there is a purpose to compare data series in the study, the data should be collected from the same participants (Creswell and Plano Clark, 2015). In this study, since the factors affecting teacher motivation were examined by comparing quantitative and qualitative data, the convenience sampling method was preferred, and the data of the study were collected over a single sample group. In the convenience sampling method, data is collected from the participants who voluntarily participated in the study (Büyüköztürk, KılıçÇakmak, Akgün, Karadeniz \& Demirel, 2016). Thus, both qualitative and quantitative data of the research were obtained from 157 Turkish Language and Literature teachers who volunteered to participate in the research. The participant demographics are presented in Table 1. 
Table 1. Participant demographics

\begin{tabular}{lll}
\hline Variable & $\mathbf{N}$ & $\mathbf{\%}$ \\
\hline Gender & 42 & 26.8 \\
Female & 115 & 73.2 \\
Male & \multicolumn{2}{c}{} \\
\hline Marital Status & 14 & 8.9 \\
Unmarried/Single (they can be handled together) & 143 & 91.1 \\
Married & 34 & 21.7 \\
\hline Professional Seniority & 95 & 60.5 \\
1-10 years & 28 & 17.8 \\
11-20 years & & \\
21 years or over & 65 & 41.4 \\
\hline High School Type & 11 & 7.0 \\
Anatolian High School & 2 & 1.3 \\
Science High School & 2 & 1.3 \\
Multi-program High School & 27 & 17.2 \\
Fine Arts High School & 47 & 29.9 \\
Religious High School & 3 & 1.9 \\
\hline Vocational High School & $\mathbf{1 5 7}$ & $\mathbf{1 0 0}$ \\
Sports High School & & \\
\hline Total & & \\
\hline
\end{tabular}

\section{Data collection instrument}

A data collection instrument that included three sections was employed in the study. The first section included questions that aimed to determine the demographic characteristics of the participants (gender, marital status, professional seniority, and type of the school of employment). Furthermore, this section included questions that aimed to determine whether they were satisfied with the attitudes and behavior of school administrators, parents, students, and colleagues towards the teachers and whether they were satisfied with the attitudes and behavior of the students towards the courses. The second section included the "Motivation to Teach Scale," developed by Kauffman, Y1lmaz-Soylu and Duke (2011) and adapted to the Turkish language by Ayık, Aktaş-Akdemir and Seçer (2015). The scale is a five-point Likerttype measurement instrument that includes two dimensions: intrinsic motivation (6 items) and extrinsic motivation (6 items). The score intervals employed in the analysis of the scale scores are presented in Table 2.

Table 2. The score intervals employed in the analysis of the scale scores

\begin{tabular}{|c|c|c|c|c|c|}
\hline Dimension & 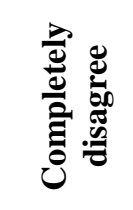 & 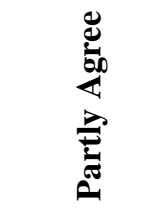 & 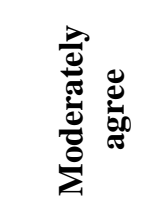 & 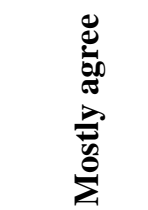 & 苞 \\
\hline Extrinsic motivation & $6-10.7$ & $10.8-15.5$ & $15.6-20.3$ & $20.4-25.1$ & $25.2-30$ \\
\hline Intrinsic Motivation & $6-10.7$ & $10.8-15.5$ & $15.6-20.3$ & $20.4-25.1$ & $25.2-30$ \\
\hline Total & $12-21.5$ & $21.6-31.1$ & $31.2-40.7$ & $40.8-50.3$ & $50.4-60$ \\
\hline
\end{tabular}

The scale fit indices values were as follows: RMSEA $=.064, \mathrm{RMR}=.010, \mathrm{NFI}=.95, \mathrm{NNFI}=$ $.96, \mathrm{CFI}=.97, \mathrm{IFI}=.97, \mathrm{RFI}=.93, \mathrm{AGFI}=.90, \mathrm{GFI}=.94$. The test-retest reliability coefficient was .92, Cronbach alpha internal consistency coefficient was .84 (Ay1k et al., 2015). In the present study, the scale Cronbach alpha internal consistency coefficient was determined as .74. The third section of the data collection included two questions: "What do 
you think about the conditions that improve your motivation to teach?" and "What do you think about the conditions that reduce your motivation to teach?"

In the qualitative section, the findings were presented for the review of five teachers to ensure internal validity, and their agreements were obtained. To ensure external validity, direct quotes of the participant statements are presented. To ensure internal reliability, the answers given by the participants in the qualitative section were read once by the two researchers. Then the data were coded based on consensus. The codes were then grouped by both authors independently based on the similarities between the codes. Then two separate code groups were reviewed. The agreement rate was calculated as $96.4 \%\left(\frac{621}{621+23} .100\right)$. The participant responses where there was a disagreement were reviewed by the two authors and these codes were grouped based on consensus. The theme titles were assigned by the two authors based on consensus. To ensure external reliability, information about the study participants, data collection, and analysis methods are explained in detail (Yıldırım \& Şimşek, 2011).

\section{Data Collection and Analysis}

The study data were collected from 163 teachers during the 2018-2019 academic year. Six forms with missing and incorrect responses were excluded and the analysis was then conducted on 157 forms. The data were analyzed for normal distribution with Shapiro-Wilks tests in cases where the group size was less than 50, and Kolmogorov-Smirnov test was used when the group size was greater than 50 (Büyüköztürk, 2012). Normality test results are shown in Table 3.

Table 3. Normality test results

\begin{tabular}{|c|c|c|c|c|c|c|c|c|c|}
\hline 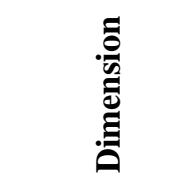 & 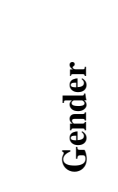 & $\mathbf{Z}$ & $\begin{array}{l}\dot{n} \\
\dot{1}\end{array}$ & $\dot{s}$ & 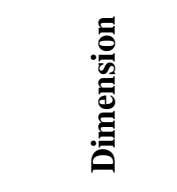 & 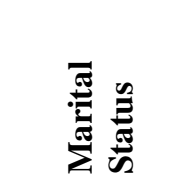 & Z & $\dot{\hat{n}}$ & $\overrightarrow{\dot{s}}$ \\
\hline $\begin{array}{l}\text { Extrinsic } \\
\text { motivation }\end{array}$ & Female & 42 & ,066 & ,222 & $\begin{array}{l}\text { Extrinsic } \\
\text { motivation }\end{array}$ & $\begin{array}{l}\text { Unmarried } \\
\text { /Single? }\end{array}$ & 14 & ,200* & ,419 \\
\hline & Male & 115 &, 054 & ,287 & & Married & 143 &, 018 & ,208 \\
\hline $\begin{array}{l}\text { Intrinsic } \\
\text { motivation }\end{array}$ & Female & 42 & ,200* & ,919 & $\begin{array}{l}\text { Intrinsic } \\
\text { motivation }\end{array}$ & Unmarried & 14 & ,200* & 820 \\
\hline & Male & 115 &, 063 & ,247 & & Married & 143 & , 200" &, 335 \\
\hline Total & Female & 42 & $200^{*}$ & ,682 & Total & Unmarried & 14 & ,200* & ,953 \\
\hline & Male & 115 &, 198 & ,483 & & Married & 143 &, 040 & ,480 \\
\hline 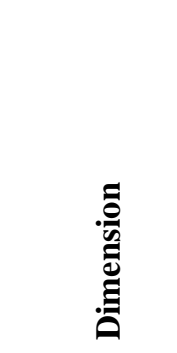 & 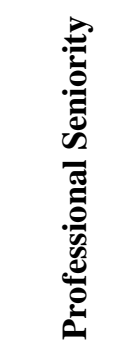 & Z & $\begin{array}{l}\dot{n} \\
\dot{\Delta}\end{array}$ & $\overrightarrow{\dot{s}}$ & 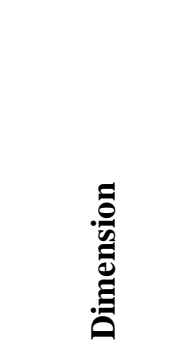 & 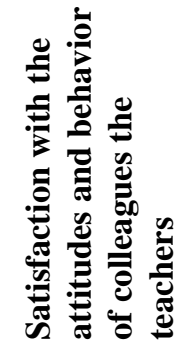 & Z & $\dot{\mathscr{n}}$ & is \\
\hline $\begin{array}{l}\text { Extrinsic } \\
\text { motivation }\end{array}$ & $\begin{array}{l}1-10 \\
\text { years }\end{array}$ & 34 & ,027 & , 160 & $\begin{array}{l}\text { Extrinsic } \\
\text { motivation }\end{array}$ & Yes & 147 & ,014 & ,317 \\
\hline & $\begin{array}{l}11-20 \\
\text { years }\end{array}$ & 95 &, $200^{*}$ & ,186 & & No & 10 & ,200* & ,391 \\
\hline
\end{tabular}




\begin{tabular}{|c|c|c|c|c|c|c|c|c|c|}
\hline & $\begin{array}{l}21 \\
\text { years } \\
\text { and } \\
\text { over }\end{array}$ & 28 & ,200* & ,557 & $\begin{array}{l}\text { Intrinsic } \\
\text { motivation }\end{array}$ & Yes & 147 & ,200* &, 300 \\
\hline \multirow[t]{3}{*}{$\begin{array}{l}\text { Intrinsic } \\
\text { motivation }\end{array}$} & $\begin{array}{l}1-10 \\
\text { years }\end{array}$ & 34 & ,200* & ,802 & & No & 10 & ,200* & ,973 \\
\hline & $\begin{array}{l}11-20 \\
\text { years }\end{array}$ & 95 & ,062 & ,210 & Total & Yes & 147 &, $200^{*}$ & ,453 \\
\hline & $\begin{array}{l}21 \\
\text { years } \\
\text { and } \\
\text { over }\end{array}$ & 28 & ,200* & ,700 & & No & 10 & ,200* & ,781 \\
\hline \multirow[t]{3}{*}{ Total } & $\begin{array}{l}1-10 \\
\text { years }\end{array}$ & 34 &, $200^{*}$ & ,871 & & & & & \\
\hline & $\begin{array}{l}11-20 \\
\text { years }\end{array}$ & 95 & ,084 & 693 & & & & & \\
\hline & $\begin{array}{l}21 \\
\text { years } \\
\text { and } \\
\text { over }\end{array}$ & 28 &, 165 & ,684 & & & & & \\
\hline
\end{tabular}

\begin{tabular}{|c|c|c|c|c|c|c|c|c|c|}
\hline 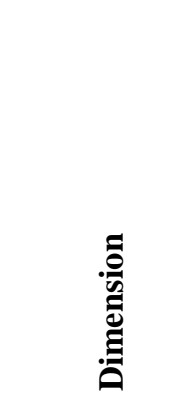 & 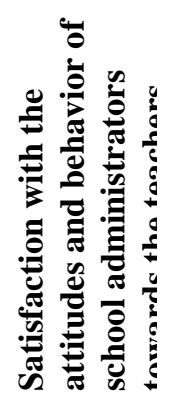 & Z & $\dot{\theta}$ & $\dot{s}$ & 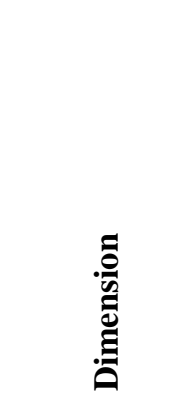 & 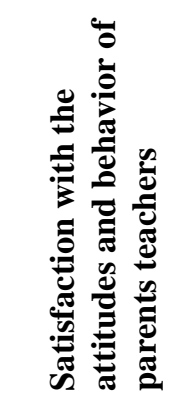 & Z & $\dot{\theta}$ & $\dot{\vec{s}}$ \\
\hline $\begin{array}{l}\text { Extrinsic } \\
\text { motivation }\end{array}$ & Yes & 133 & ,027 & ,399 & $\begin{array}{l}\text { Extrinsic } \\
\text { motivation }\end{array}$ & Yes & 126 & ,200* &, 523 \\
\hline & No & 24 & ,200* & 880 & & No & 31 & ,065 & ,083 \\
\hline $\begin{array}{l}\text { Intrinsic } \\
\text { motivation }\end{array}$ & Yes & 133 & ,200* & ,340 & $\begin{array}{l}\text { Intrinsic } \\
\text { motivation }\end{array}$ & Yes & 126 & ,200* & ,186 \\
\hline & No & 24 & 048 & ,151 & & No & 31 & , 200* & 131 \\
\hline Total & $\begin{array}{l}\text { Yes } \\
\text { No }\end{array}$ & $\begin{array}{l}133 \\
24\end{array}$ & $\begin{array}{l}\frac{200^{*}}{200^{*}} \\
\end{array}$ & $\begin{array}{l}, 707 \\
705\end{array}$ & Total & $\begin{array}{l}\text { Yes } \\
\text { No }\end{array}$ & $\frac{126}{31}$ & $\frac{, 033}{200^{*}}$ & $\begin{array}{r}057 \\
717\end{array}$ \\
\hline 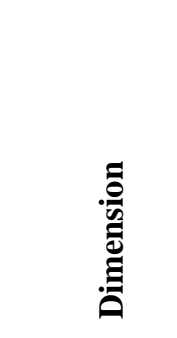 & 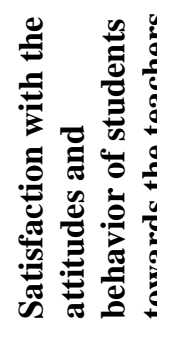 & Z & $\dot{0}$ & $\dot{\vec{s}}$ & 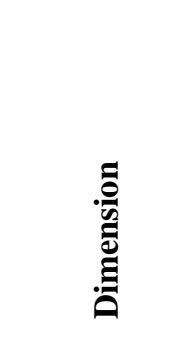 & 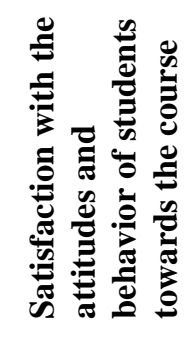 & Z & $\dot{n}$ & is \\
\hline $\begin{array}{l}\text { Extrinsic } \\
\text { motivation }\end{array}$ & Yes & 110 & ,048 & ,372 & $\begin{array}{l}\text { Extrinsic } \\
\text { motivation }\end{array}$ & Yes & 75 & ,032 & ,181 \\
\hline & No & 47 & ,036 & ,467 & & No & 82 & ,094 & ,414 \\
\hline $\begin{array}{l}\text { Intrinsic } \\
\text { motivation }\end{array}$ & Yes & 110 & ,200* & ,359 & $\begin{array}{l}\text { Intrinsic } \\
\text { motivation }\end{array}$ & Yes & 75 & ,200* & ,712 \\
\hline & No & 47 & $\begin{array}{l}, 200^{*} \\
\end{array}$ & ,374 & & No & 82 & $\begin{array}{l}, 200^{*} \\
\end{array}$ &, 444 \\
\hline Total & Yes & 110 & 050 &, 087 & Total & Yes & 75 & , 200* & ,392 \\
\hline & No & 47 & ,200* & ,710 & & No & 82 & , 200* & 641 \\
\hline
\end{tabular}


In order to use parametric tests in data analysis, the data of the variable in each group in the independent variable to be analysed should be distributed normally (Seçer,2017). According to Table 3, the data show normal distribution only in terms of gender and professional seniority. Parametric tests were used for variables in which the data showed normal distribution, and non-parametric tests were used for variables that did not show normal distribution. In order to determine whether the difference between two unrelated sample means is significant, $t$ test is used in parametric tests and Mann Whitney $U$ test is used in nonparametric tests. One way analysis of variance is used in parametric tests to determine whether the difference between more than two unrelated sample means is significant. (Büyüköztürk, 2012). In this respect, $t$ test was used to determine whether there is a significant difference between the perceptions of the participants in terms of gender variable. One-way analysis of variance was used to determine whether there was a significant difference between the perceptions of the participants in terms of professional seniority variable. In the respect of other variables (satisfaction with school administrators' attitudes and behaviours, satisfaction with parents' attitudes and behaviours, satisfaction with students' attitudes and behaviours, satisfaction with students' attitudes and behaviours toward the course, satisfaction with colleagues' attitudes and behaviours) Mann Whitney U test was used to determine whether there was a significant difference between the perceptions of the participants.

Descriptive statistics, independent samples t-test, Mann-Whitney $U$ test, and one-way analysis of variance were employed in data analysis. Furthermore, Eta-square and Cohen's d values were calculated to determine the effect size. In eta-square, .01 was interpreted as small, .06 was interpreted as moderate and .14 was interpreted as large effect size. In Cohen's d, regardless of the sign, .2 was interpreted as small, .5 was interpreted as moderate and .8 was interpreted as large effect size. In the Mann Whitney $U$ test, a Cohen criteria of .1 was determined as small, .3 was determined as moderate and .5 was determined as a large effect size (Pallant, 2017).

Content analysis was employed in qualitative data analysis. Initially, the data were coded, and similar codes were grouped to determine the themes. Frequencies were calculated for each code.

\section{Results}

Descriptive statistics on the perceptions of the participants about motivation to teach are presented in Table 4.

Table 4. The perceptions about motivation to teach

\begin{tabular}{lcccccc}
\hline Dimension & $\mathbf{N}$ & Minimum & Maximum & $\overline{\boldsymbol{x}}$ & SS & Level \\
\hline $\begin{array}{l}\text { Extrinsic } \\
\text { motivation }\end{array}$ & 157 & 6.00 & 27.00 & 14.89 & 4.05 & $\begin{array}{l}\text { Partially } \\
\text { agree }\end{array}$ \\
\hline $\begin{array}{l}\text { Intrinsic } \\
\text { motivation }\end{array}$ & 157 & 6.00 & 30.00 & 17.15 & 5.01 & $\begin{array}{l}\text { Moderately } \\
\text { agree }\end{array}$ \\
\hline Total & 157 & 12.00 & 57.00 & 32.04 & 7.87 & $\begin{array}{l}\text { Moderately } \\
\text { agree }\end{array}$ \\
\hline
\end{tabular}

Arithmetic mean values were examined to determine the level of the participants' perception of teaching motivation. In Table 4, it was indicated that teachers had moderate perceptions $(\bar{x}$ $=32.04)$ in terms of the overall motivation to teach, with partially agreement with extrinsic motivation $(\bar{x}=14.89)$, and moderate agreement with intrinsic motivation $(\bar{x}=17.15)$. 
The results of the t-test conducted to analyze the perceptions of the participants about motivation to teach based on gender variable are presented in Table 5.

Table 5. The analysis of the perceptions about motivation to teach based on gender variable

\begin{tabular}{llllllllll}
\hline Dimension & Gender & $\mathbf{N}$ & $\overline{\boldsymbol{x}}$ & $\mathbf{S S}$ & $\mathbf{s d}$ & $\mathbf{t}$ & $\mathbf{p}$ & $\begin{array}{l}\text { Eta- } \\
\text { square }\end{array}$ & $\begin{array}{l}\text { Cohen's } \\
\mathbf{d}\end{array}$ \\
\hline Extrinsic & Female & 42 & 13.75 & 4.07 & 155 & -2.153 & $\mathbf{. 0 3 3}$ & $\mathbf{. 0 3}$ & $\mathbf{- . 3 9}$ \\
motivation & Male & 115 & 15.31 & 3.99 & & & & & \\
\hline Intrinsic & Female & 42 & 18.13 & 4.65 & 155 & 1.489 & .138 & & \\
motivation & Male & 115 & 16.79 & 5.11 & & & & & \\
\hline Total & Female & 42 & 31.88 & 7.55 & 155 & -.151 & .880 & & \\
\hline & Male & 115 & 32.09 & 8.02 & & & & &
\end{tabular}

Note: The data are distributed normally for this variable.

As seen in Table 5, there was a significant difference between the extrinsic motivation perceptions of the teachers based on the gender variable $(\mathrm{t}(155)=-2.153, \mathrm{p}<.05)$. Extrinsic motivation perceptions of male teachers $(\bar{x}=15.31)$ were higher when compared to female teachers $(\bar{x}=13.75)$. Eta square analysis $(.03)$ demonstrated that $3 \%$ of the variance observed in extrinsic motivation was explained by gender. Cohen's $d$ analysis (-.39) revealed that the difference between the mean extrinsic motivation perception scores of the male and female teachers was about .39. Gender had a small impact on extrinsic motivation based on both effect sizes.

The results of the Mann Whitney U-test conducted to analyze the perceptions of the participants about motivation to teach based on the marital status variable are presented in Table 6.

Table 6. The analysis of the perceptions about motivation to teach based on the marital status variable

\begin{tabular}{lllllll}
\hline Dimension & Marital Status & $\mathbf{n}$ & Mean Rank & Total Rank & U & p \\
\hline Extrinsic & Unmarried & 14 & 59.79 & 837.00 & 732.00 & .097 \\
motivation & Married & 143 & 80.88 & 11566.00 & & .309 \\
\hline Intrinsic & Unmarried & 14 & 90.79 & 1271.00 & 836.00 & .875 \\
motivation & Married & 143 & 77.85 & 11132.00 & & 975.50 \\
\hline \multirow{2}{*}{ Total } & Unmarried & 14 & 77.18 & 1080.50 & & \\
& Married & 143 & 79.18 & 11322.50 & & \\
\hline
\end{tabular}

Note: The data are not distributed normally for this variable.

Based on Table 6, there was no significant difference between the motivation to teach perceptions of the teachers based on the marital status variable ( $p>.05)$.

The results of the one-way analysis of variance conducted to analyze the perceptions of the participants about motivation to teach based on the professional seniority variable are presented in Table 7.

Table 7. The analysis of the perceptions about motivation to teach based on the professional seniority variable

\begin{tabular}{llllllll}
\hline Dimension & Professional Seniority & N & $\bar{X}$ & SS & sd & F & p \\
\hline \multirow{2}{*}{ Extrinsic } & 1-10 years & 34 & 14.04 & 3.87 & 2 & .957 & .386 \\
motivation & 11-20 years & 95 & 15.10 & 4.00 & 154 & & \\
& 21 years and over & 28 & 15.19 & 4.47 & & & .319 \\
Intrinsic & 1-10 years & 34 & 17.55 & 4.65 & 2 & 1.152 & \\
motivation & 11-20 years & 95 & 16.69 & 4.95 & 154 & & \\
& 21 years and over & 28 & 18.22 & 5.60 & & & \\
\hline
\end{tabular}




\begin{tabular}{llllllll}
\hline \multirow{3}{*}{ Total } & 1-10 years & 34 & 31.59 & 7.26 & 2 & .525 & .593 \\
& 11-20 years & 95 & 31.79 & 7.75 & 154 & & \\
\hline
\end{tabular}

Note: The data are distributed normally for this variable.

Based on Table 7, there was no significant difference between the motivation to teach perceptions of the teachers based on the professional seniority variable ( $p>.05)$.

The results of the Mann Whitney U-test conducted to analyze the perceptions of the participants about motivation to teach based on their satisfaction with the attitudes and behavior of school administrators towards the teachers are presented in Table 8 .

Table 8. The analysis of the perceptions about motivation to teach based on their satisfaction with the attitudes and behavior of school administrators towards the teachers

\begin{tabular}{llllllll}
\hline Dimension & $\begin{array}{l}\text { Satisfaction with } \\
\text { the attitudes and } \\
\text { behavior of school } \\
\text { administrators } \\
\text { towards the } \\
\text { teachers }\end{array}$ & $\mathbf{N}$ & Mean Rank & $\begin{array}{l}\text { Total } \\
\text { Rank }\end{array}$ & $\mathbf{U}$ & $\mathbf{p}$ & $\mathbf{r}$ \\
\hline Extrinsic & Yes & 133 & 81.55 & 10846.50 & 1256.50 & .097 \\
motivation & No & 24 & 64.85 & 1556.50 & & \\
\hline Intrinsic & Yes & 133 & 81.52 & 10842.00 & 1261.00 & .102 \\
motivation & No & 24 & 65.04 & 1561.00 & & \\
\hline Total & Yes & 133 & 82.06 & 10914.50 & 1188.50 & $\mathbf{. 0 4 7}$ & $\mathbf{. 1 6}$ \\
\hline No & 24 & 62.02 & 1488.50 & & \\
\hline
\end{tabular}

Note: The data are not distributed normally for this variable.

As seen in Table 8, there was a significant difference between the motivation to teach perceptions of the teachers based on satisfaction with the attitudes and behavior of school administrators towards the teachers $(\mathrm{U}=1188.50, \mathrm{p}<.05)$. Based on the mean rank findings, the motivation to teach perceptions of the teachers who were satisfied with the attitudes and behavior of school administrators towards the teachers were higher when compared to those who were not satisfied. Cohen's criteria revealed that the effect of satisfaction with the attitudes and behavior of school administrators towards the teachers on the total motivation to teach perceptions of the teachers (.16) was small.

The results of the Mann Whitney U-test conducted to analyze the perceptions of the participants about motivation to teach based on their satisfaction with the attitudes and behavior of the parents towards the teachers are presented in Table 9.

Table 9. The analysis of the perceptions about motivation to teach based on their satisfaction with the attitudes and behavior of the parents towards the teachers

\begin{tabular}{|c|c|c|c|c|c|c|c|}
\hline Dimension & $\begin{array}{l}\text { Satisfaction with } \\
\text { the attitudes and } \\
\text { behavior of } \\
\text { parents towards } \\
\text { the teachers }\end{array}$ & $\mathbf{N}$ & $\begin{array}{l}\text { Mean } \\
\text { Rank }\end{array}$ & Total Rank & $\mathbf{U}$ & $\mathbf{p}$ & $\mathbf{r}$ \\
\hline \multirow{2}{*}{$\begin{array}{l}\text { Extrinsic } \\
\text { motivation }\end{array}$} & Yes & 126 & 82.02 & 10334.00 & \multirow[t]{2}{*}{1573.00} & \multirow[t]{2}{*}{.093} & \\
\hline & No & 31 & 66.74 & 2069.00 & & & \\
\hline \multirow{2}{*}{$\begin{array}{l}\text { Intrinsic } \\
\text { motivation }\end{array}$} & Yes & 126 & 82.81 & 10433.50 & \multirow[t]{2}{*}{1473.50} & \multirow[t]{2}{*}{.034} & \multirow[t]{2}{*}{.17} \\
\hline & No & 31 & 63.53 & 1969.50 & & & \\
\hline \multirow{2}{*}{ Total } & Yes & 126 & 83.02 & 10460.50 & \multirow[t]{2}{*}{1446.50} & \multirow[t]{2}{*}{.025} & \multirow[t]{2}{*}{.18} \\
\hline & No & 31 & 62.66 & 1942.50 & & & \\
\hline
\end{tabular}

Note: The data are not distributed normally for this variable. 
As seen in Table 9, there was a significant difference between the total motivation to teach perceptions $(U=1446.50, \mathrm{p}<.05)$ and intrinsic motivation perceptions $(U=1473.50, \mathrm{p}<.05)$ of the teachers based on satisfaction with the attitudes and behavior of parents towards the teachers. Based on the mean rank findings, the motivation to teach perceptions of the teachers who were satisfied with the attitudes and behavior of parents towards the teachers were higher when compared to those who were not satisfied. Cohen's criteria revealed that the effects of satisfaction with the attitudes and behavior of parents towards the teachers on the total motivation to teach perceptions (.18) and intrinsic motivation of the teachers (.17) were small.

The results of the Mann Whitney U-test conducted to analyze the perceptions of the participants about motivation to teach based on their satisfaction with the attitudes and behavior of the students towards the teachers are presented in Table 10.

Table 10. The analysis of the perceptions about motivation to teach based on their satisfaction with the attitudes and behavior of the students towards the teachers

\begin{tabular}{|c|c|c|c|c|c|c|c|}
\hline Dimension & $\begin{array}{l}\text { Satisfaction with } \\
\text { the attitudes and } \\
\text { behavior of } \\
\text { students towards } \\
\text { the teachers }\end{array}$ & $\mathbf{N}$ & Mean Rank & $\begin{array}{l}\text { Total } \\
\text { Rank }\end{array}$ & $\mathbf{U}$ & $\mathbf{p}$ & $\mathbf{r}$ \\
\hline \multirow{2}{*}{$\begin{array}{l}\text { Extrinsic } \\
\text { motivation }\end{array}$} & Yes & 110 & 82.83 & 9111.50 & \multirow[t]{2}{*}{2163.50} & \multirow[t]{2}{*}{.105} & \\
\hline & No & 47 & 70.03 & 3291.50 & & & \\
\hline \multirow{2}{*}{$\begin{array}{l}\text { Intrinsic } \\
\text { motivation }\end{array}$} & Yes & 110 & 84.25 & 9267.50 & \multirow[t]{2}{*}{2007.50} & \multirow[t]{2}{*}{.027} & \multirow[t]{2}{*}{.18} \\
\hline & No & 47 & 66.71 & 3135.50 & & & \\
\hline \multirow{2}{*}{ Total } & Yes & 110 & 84.17 & 9259.00 & \multirow[t]{2}{*}{2016.00} & \multirow[t]{2}{*}{.029} & \multirow[t]{2}{*}{.17} \\
\hline & No & 47 & 66.89 & 3144.00 & & & \\
\hline
\end{tabular}

Note: The data are not distributed normally for this variable.

As seen in Table 10, there were significant differences between the total motivation to teach perceptions $(\mathrm{U}=2016.00, \mathrm{p}<.05)$ and intrinsic motivation perceptions $(\mathrm{U}=2007.50, \mathrm{P}<.05)$ of the teachers based on satisfaction with the attitudes and behavior of students towards the teachers. Based on the mean rank findings, the motivation to teach perceptions of the teachers who were satisfied with the attitudes and behavior of students towards the teachers were higher when compared to those who were not satisfied. Cohen's criteria revealed that the effects of satisfaction with the attitudes and behavior of the students towards the teachers on the total motivation to teach perceptions (.17) and intrinsic motivation of the teachers (.18) were small.

The results of the Mann Whitney U-test conducted to analyze the perceptions of the participants about motivation to teach based on their satisfaction with the attitudes and behavior of the students towards the course are presented in Table 11.

Table 11. The analysis of the perceptions about motivation to teach based on their satisfaction with the attitudes and behavior of the students towards the course

\begin{tabular}{llcccccc}
\hline Dimension & $\begin{array}{l}\text { Satisfaction with the } \\
\text { attitudes and behavior of } \\
\text { students towards the course }\end{array}$ & $\mathbf{N}$ & $\begin{array}{l}\text { Mean } \\
\text { Rank }\end{array}$ & $\begin{array}{l}\text { Total } \\
\text { Rank }\end{array}$ & $\mathbf{U}$ & $\mathbf{p}$ & $\mathbf{r}$ \\
\hline Extrinsic & Yes & 75 & 86.75 & 6506.50 & 2493.50 & $\mathbf{. 0 4 1}$ & $\mathbf{. 1 6}$ \\
motivation & No & 82 & 71.91 & 5896.50 & & & \\
\hline Intrinsic & Yes & 75 & 88.23 & 6617.50 & 2382.50 & $\mathbf{. 0 1 5}$ & $\mathbf{. 1 9}$ \\
motivation & No & 82 & 70.55 & 5785.50 & & & \\
\hline \multirow{2}{*}{ Total } & Yes & 75 & 88.90 & 6667.50 & 2332.50 & $\mathbf{. 0 0 9}$ & $\mathbf{. 2 1}$ \\
& No & 82 & 69.95 & 5735.50 & & & \\
\hline
\end{tabular}

Note: The data are not distributed normally for this variable. 
As seen in Table 11, there were significant differences between the total motivation to teach perceptions $(U=2332.50, p<.05)$, extrinsic motivation perceptions $(U=2493.50, p<.05)$, and intrinsic motivation perceptions $(\mathrm{U}=2382.50, \mathrm{p}<.05)$ of the teachers based on satisfaction with the attitudes and behavior of students towards the Turkish Language and Literature course. Based on the mean rank findings, the motivation to teach perceptions, intrinsic and extrinsic motivations of the teachers who were satisfied with the attitudes and behavior of students towards the course were higher when compared to those who were not satisfied. Cohen's criteria revealed that the effects of satisfaction with the attitudes and behavior of the students towards the course on the total motivation to teach perceptions (.21), extrinsic motivation (.16), and intrinsic motivation (.19) of the teachers were small.

The results of the Mann Whitney U-test conducted to analyze the perceptions of the participants about motivation to teach based on their satisfaction with the attitudes and behavior of their colleagues towards the teachers are presented in Table 12.

Table 12. The analysis of the perceptions about motivation to teach based on their satisfaction with the attitudes and behavior of colleagues towards the teachers

\begin{tabular}{|c|c|c|c|c|c|c|c|}
\hline Dimension & $\begin{array}{l}\text { Satisfaction with } \\
\text { the attitudes and } \\
\text { behavior of } \\
\text { colleagues towards } \\
\text { the teachers }\end{array}$ & $\mathbf{N}$ & Mean Rank & $\begin{array}{l}\text { Total } \\
\text { Rank }\end{array}$ & $\mathbf{U}$ & $\mathbf{p}$ & $\mathbf{r}$ \\
\hline $\begin{array}{l}\text { Extrinsic } \\
\text { motivation }\end{array}$ & $\begin{array}{l}\text { Yes } \\
\text { No }\end{array}$ & $\begin{array}{l}147 \\
10 \\
\end{array}$ & $\begin{array}{l}80.71 \\
53.80 \\
\end{array}$ & $\begin{array}{l}11865.00 \\
538.00\end{array}$ & 483.00 & .069 & \\
\hline $\begin{array}{l}\text { Intrinsic } \\
\text { motivation }\end{array}$ & $\begin{array}{l}\text { Yes } \\
\text { No }\end{array}$ & $\begin{array}{l}147 \\
10\end{array}$ & $\begin{array}{l}81.28 \\
45.55 \\
\end{array}$ & $\begin{array}{l}11947.50 \\
455.50\end{array}$ & 400.50 & .016 & .19 \\
\hline Total & $\begin{array}{l}\text { Yes } \\
\text { No }\end{array}$ & $\begin{array}{l}147 \\
10\end{array}$ & $\begin{array}{l}81.24 \\
46.05\end{array}$ & $\begin{array}{l}11942.50 \\
460.50\end{array}$ & 405.50 & .018 & .19 \\
\hline
\end{tabular}

Note: The data are not distributed normally for this variable.

As seen in Table 12, there were significant differences between the total motivation to teach perceptions $(\mathrm{U}=405.50, \mathrm{p}<.05)$ and intrinsic motivation perceptions $(\mathrm{U}=400.50, \mathrm{p}<.05)$ of the teachers based on satisfaction with the attitudes and behavior of colleagues towards the teachers. Based on the mean rank findings, the motivation to teach perceptions and intrinsic motivation of the teachers who were satisfied with the attitudes and behavior of colleagues towards the teachers were higher when compared to those who were not satisfied. Cohen's criteria revealed that the effects of satisfaction with the attitudes and behavior of colleagues towards the teachers on the total motivation to teach perceptions (.19) and intrinsic motivation (.19) of the teachers were small.

The views of the participants on the factors that improve the motivation to teach are presented in Table 13.

Table 13. The views on the factors that improve the motivation to teach

\begin{tabular}{lll}
\hline \multicolumn{2}{l}{ The factors that improve the motivation to teach } & $\mathbf{n}$ \\
\hline Theme & Academic interest and competency of the student & 82 \\
\hline \multirow{2}{*}{ Student } & Positive attitudes and behavior of the student towards the teacher & 7 \\
\hline & Improvement of the prestige of teaching profession & 49 \\
& Improvement of the income level of the teachers & 37 \\
\multirow{2}{*}{ Government } & Teacher autonomy & 12 \\
& Improvement of the influence of teachers on education process & 7 \\
& Improvement of the personal rights of the teachers & 6
\end{tabular}




\begin{tabular}{|c|c|c|}
\hline & Reduction of extracurricular activities (red tape, school activity duties, etc.) & 6 \\
\hline & Simplification of the curriculum & 4 \\
\hline & Merit-based teacher evaluation & 3 \\
\hline & Reduction of exam anxiety & 3 \\
\hline & Abolishment of compulsory education & 3 \\
\hline & Reduction of course load & 3 \\
\hline & Compatibility of university admittance exam content and the curriculum & 3 \\
\hline & Enaction of teaching profession law & 2 \\
\hline & Improvement of career opportunities for teachers & 2 \\
\hline & $\begin{array}{l}\text { Increasing the weight of the Turkish language and literature course in the } \\
\text { university admittance exam }\end{array}$ & 2 \\
\hline & Avoidance of changing the curriculum frequently & 1 \\
\hline & Avoidance of changing the system frequently & 1 \\
\hline & Appointment of administrators based on merit & 1 \\
\hline & Association of the curriculum with daily life & 1 \\
\hline & Adoption of knowledge-oriented learning methods & 1 \\
\hline & Expanding interesting content in textbooks & 1 \\
\hline & Adequacy of physical conditions at schools & 19 \\
\hline & Psychological satisfaction & 9 \\
\hline & Collaboration & 6 \\
\hline & Improvement of sociocultural activities & 5 \\
\hline Work environment & Discipline & 5 \\
\hline & Healthy communications & 2 \\
\hline & Qualified teaching personnel & 2 \\
\hline & Cooperation among field teachers & 1 \\
\hline & A critical environment & 1 \\
\hline School & The attitudes of the school administrator towards teachers & 25 \\
\hline administrator & Fair administration & 4 \\
\hline & Interested and aware parents & 10 \\
\hline Parents & Positive attitudes and behavior of parents towards teachers & 3 \\
\hline & Improvement of personal development & 3 \\
\hline Personal & Love for teaching & 1 \\
\hline
\end{tabular}

Note: $\mathrm{n}$ represents the number of participants.

As seen in Table 13, the views of the teachers on the factors that improve the motivation to teach were grouped under six themes: student, government, work environment, school administrator, parents, and personal. While the most frequently mentioned theme was "student", the least mentioned theme was "personal". Based on the views in the "student" theme, teachers' motivation to teach increased when the students were academically interested and competent and exhibited positive attitudes and behavior towards the teacher. While the improvement of the prestige of the teaching profession was the most frequently mentioned factor in the theme of "government", the improvement of the income levels of the teachers, teacher autonomy, and the improvement of the influence of teachers on the education process were also frequently mentioned. The adequacy of the physical school conditions was emphasized most frequently in the theme of "work environment", psychological satisfaction, cooperation, the improvement of socio cultural activities, and discipline were also emphasized. Based on the views in the theme of "school administrator", it was stated that fair administration and positive attitudes and behavior of the school administrator towards the teacher improved the motivation to teach of the teachers. Based on the views in the "parents" theme, it was determined that the interest and awareness of the parents, as well as their positive attitudes and behavior towards the teacher improved the motivation to teach. Based on the views in the "personal" theme, improvement of the personal development of the teacher, and the teacher's love for teaching improved the motivation to teach according to the participants. 
Certain participants stated the following on the factors that improve the motivation to teach as follows:

T2. "The student should be prepared for the lesson, have the course material, be interested, and ask questions." (Theme: Student).

T122. "Particularly, our students' interest in the course and the feedback I receive from the students have a positive effect on my motivation to teach.” (Theme: Student).

T15. "If teaching was a more respected profession in the society and the income (financial) was better, if the curriculum was simplified and based on more realistic foundations, and unnecessary knowledge and activities were removed, these would contribute to my motivation." (Theme: Government).

T75. "When the level of student's readiness is high, when the student is willing, the parents are interested, and the classes in the school have adequate technical equipment (In my school there are still no smartboards or projectors) (I become motivated?). The supportive attitude of the school administration improves my motivation to teach." (Theme: Student, Parents, Work environment, School administrator).

According to the views that mentioned above, students' academic interest and competence, increasing the prestige of the teaching profession, improving teachers' economic conditions, simplifying the curriculum, making the physical conditions of the school sufficient, parents' involvement and school administrators' support increase the motivation to teach.

The views of the participants on the factors that reduce the motivation to teach are presented in Table 14.

Table 14. The views on the factors that reduce the motivation to teach

\begin{tabular}{lll}
\hline The factors that reduce the motivation to teach & n \\
\hline Theme & Academic disinterest and incompetency of the student & 84 \\
Student & Negative attitudes and behavior of the student towards the teacher & 24 \\
\hline & Reduction in the prestige of teaching profession & 36 \\
Inability to improve the income level of the teachers & 21 \\
High level of extracurricular activities (red tape, school activity duties, etc.) & 10 \\
Lack of teacher autonomy & 8 \\
Frequent changes in the system & 5 \\
Extensive curricular content & 4 \\
Compulsory education & 3 \\
Frequent changes in the curriculum & 3 \\
Extensive course load & 3 \\
Non-merit-based teacher evaluation & 2 \\
Inadequate personal rights & 2 \\
Lack of career opportunities & 2 \\
The high number of questions in textbooks & 1 \\
The measurement of only academic achievements & 1 \\
Dependence on only textbooks & 1 \\
Test-based student evaluation & Exam anxiety \\
The lack of guidance courses organized by the Ministry of National education & 1 \\
(for the school, parents and students) & 1 \\
The low weight of the Turkish language and literature course in the university & 1 \\
admittance exam &
\end{tabular}




\begin{tabular}{lll}
\hline & Curriculum not associated with daily life & 1 \\
\hline \multirow{2}{*}{ School administrator } & The negative attitudes of the school administrator towards teachers & 24 \\
& Unfair administration & 7 \\
\hline \multirow{2}{*}{ Parents } & Disinterested and unaware parents & 17 \\
& Negative attitudes and behavior of parents towards teachers & 8 \\
\hline & Inadequacy of physical conditions at schools & 15 \\
& Lack of psychological satisfaction & 4 \\
& Lack of discipline & 2 \\
\multirow{5}{*}{ Work environment } & Miscommunication & 2 \\
& Negative relations with colleagues & 1 \\
& Few sociocultural activities & 1 \\
& A non-innovative environment & 3 \\
\hline \multirow{2}{*}{ Personal } & Familial problems & 3 \\
& Personal problems (illness, etc.) & 1 \\
\hline
\end{tabular}

Note: $\mathrm{n}$ represents the number of participants.

As seen in Table 14, the views of the teachers on the factors that reduce the motivation to teach were grouped under six themes: student, government, school administrator, parent, work environment, and personal. While the most frequently mentioned theme was "student", the least emphasized theme was "personal". Based on the views in the theme of "student", it was argued that the academic disinterest and inadequacy of the students and their negative attitudes and behavior towards the teacher reduced the teaching motivation of the teachers. While the reduction in the prestige of the teaching profession was most frequently mentioned in the theme of "government", inability to improve the income of the teachers, high level of extracurricular activities (red tape, assignments in school activities, and others.), and the lack of teacher autonomy were also emphasized. Based on the views in the theme of "school administration", it was stated that the unfair management style of the school administration and the negative attitudes and behavior towards the teacher reduced the motivation to teach. Based on the views in the "parents" theme, the lack of awareness and indifference of the parents, and negative attitudes and behavior towards the teacher reduced the motivation to teach. While the inadequacy of the physical school conditions was emphasized most frequently in the theme of "work environment", the lack of psychological satisfaction and discipline were also emphasized. Based on the views in the "personal" theme, family problems, personal difficulties, and lack of personal development opportunities reduced the motivation to teach.

Certain participants stated the following on the factors that reduce the motivation to teach as follows:

T44. "The students' disinterest in the course, disrespect, and dislike of our course and the fact that they do not read books." (Theme: Student).

T122. "The fact that students come to the class unprepared and their indifference toward the course. Negative behavior inside and outside the class." (Theme: Student).

T12. "The fact that I feel under pressure, the low impact of my course on the university exam, intensive curriculum." (Theme: Government).

T87. "Encountering an unwilling and uninterested student body. Being in an unhappy school environment where healthy communications cannot be established. The intensive and everchanging curriculum. Spending more time in extracurricular activities." (Theme: Student, 
Work environment, Government).

T107. "Students' disinterest, disrespect and negative attitudes of the administration." (Theme: Student, School administrator).

T112. "Frequent changes in the education system. Careless, indifferent, and irresponsible behavior of the students. Unnecessary workload (coaching, parent visits, continuous requests for documents, etc.), some of which I think are not beneficial at all, lack of tools in the school (smart board)." (Theme: Government, Student, Work environment).

T138. "Difficult economic conditions. Low student and parent interest. Decreased prestige of the profession in the society." (Theme: Government, Student, Parents).

In the scope of the views that were mentioned above, students' academic incompetence and irrelevance, negative attitudes and behaviours towards teachers, lack of teacher autonomy, lower weight of the course in the university exam, intensive curriculum, frequent changes in the curriculum, excessive extracurricular activities, an unhappy working environment, lack of communication, negative attitudes and behaviours of the school administrator, frequent changes in the education system, insufficiency in the physical conditions of the school, economic difficulties, indifference of parents, and the decrease in the prestige of the teaching profession diminish the motivation to teach.

\section{Discussion, Conclusion and Suggestions}

In the present study that aimed to investigate teachers' motivation to teach and to determine the factors that affected their motivation, it was found that teachers' motivation to teach was moderate. In terms of dimensions, teachers' intrinsic motivation perceptions are higher than their extrinsic motivation perceptions. Ertürk (2016) reported similar findings on the job motivation of the teachers. According to Argon and Cicioğlu (2017), motivation to teach in vocational high school teachers was low and their intrinsic motivation was higher than their extrinsic motivation. Sarı, Canoğulları and Yıldız (2018) determined that teachers' professional motivation was high. Hein et al. (2012) determined that the intrinsic motivation of physical education teachers was higher than their extrinsic motivation. The fact that extrinsic motivation was lower than intrinsic motivation could be an indicator of the inadequacy of external factors that motivate the teachers. In fact, based on the qualitative findings in the study, while extrinsic motivation factors were mostly emphasized among factors that increase or decrease teachers' motivation, intrinsic motivation factors were rarely emphasized. On the other hand, although both motivations are important, the teachers are desired to have intrinsic motivation (Yazic1, 2009). Since intrinsic motivation leads to quality learning and creativity, it is considered significant in education. There are important differences between the performances of those who were motivated by intrinsic and extrinsic factors (Ryan \& Deci, 2000). Teachers with intrinsic motivation employ more productive instruction styles (Hein et al. 2012). While internally motivated individuals focus on their work processes, externally motivated individuals focus on the outcomes (Kauffman et al., 2011). Furthermore, it was reported that the main source of motivation was intrinsic motivation, and extrinsic motivation could increase the level of motivation if intrinsic motivators are present (Sinclair, 2008). In addition, although intrinsic and extrinsic motivation factors are positively correlated with teachers' job satisfaction, intrinsic motivation factors have a greater effect on job satisfaction (Nadim, Chaudhry, Kalyar \& Riaz, 2012).

The present study's quantitative findings revealed no significant difference between the 
teachers' motivation to teach based on marital status and professional seniority variables. Based on the gender variable, there was a significant difference between the extrinsic motivation perceptions of teachers favoring the male teachers. However, it was determined that the effect of gender on extrinsic motivation was small. On the other hand, in the qualitative dimension of the study, no evidence was found that the marital status of the teachers and their professional seniority and gender affected their motivation to teach. The previous study findings were not consistent with the impact of personal variables on teacher motivation. For example, Argon and Cicioğlu (2017) concluded that there was no significant difference between vocational high school teachers' motivations to teach based on gender. Sar1 et al. (2018a) determined that there was no significant difference between the professional motivation of teachers based on gender and professional seniority. Ertürk (2016) reported a significant difference between teachers' intrinsic, extrinsic, and total job motivations based on professional seniority. Emiroğlu (2017) determined that women's intrinsic motivation sources were more than men's but did not find any significant difference between their extrinsic motivation sources. The study concluded that there was no significant difference based on professional seniority. Tulunay-Ateş and Bulut (2018), on the other hand, determined that there was a significant difference between intrinsic and extrinsic motivations of teachers favoring women, while there were no significant differences based on marital status and professional seniority.

The quantitative findings of the present study revealed a significant difference between the perceptions of the teachers on total motivation to teach based on their satisfaction with the attitudes and behavior of the school administrators towards the teachers. Teachers who were satisfied with the attitudes and behavior of school administrators towards the teachers had better total motivation to teach perceptions when compared to those who were not satisfied. This finding may suggest that the teachers' satisfaction with the attitudes and behavior of school administrators towards the teachers affected their motivation to teach. However, it was determined that the effect was small. The present study's qualitative findings demonstrated that according to certain teachers, school administrators were among the factors that increased or decreased teachers' motivation to teach. Positive attitudes such as the support provided by school administrators, as well as their appreciation, respect, trust, understanding, improved teachers' motivation to teach. When school administrators do not support teachers, do not trust or understand them, and are oppressive, and if they do not allow them to participate in decision-making processes about the school, or do not notice their work, teachers' motivation to teach is affected negatively. Furthermore, school administrators who adopt a fair administration style improve teachers' motivation to teach, while those who exhibit an unfair administration style reduce their motivation to teach. Thus, the qualitative findings also demonstrated that school administrators' attitudes and behavior towards the teachers were a factor that affected teacher motivation. In this respect, it can be said that the result obtained in quantitative research was supported by qualitative research results. It could be suggested that this finding was consistent with the findings reported by the studies in the literature. For instance, according to Börü (2018), when school principals are fair, appreciate the teachers, are tolerant, and respect the teachers, the teacher motivation increases. Doğan and Koçak (2017) reported that administrators who respect teachers and their work, are sensitive to their needs, and demonstrate democratic behavior positively affect teacher motivation. According to Ada, Akan, Ayık, Yıldırım, and Yalçın (2013), administrators who trust, support, understand and appreciate teachers and exhibit fair management increased extrinsic motivation; however, disinterested administrators, oppressive school administration, unfair administrators, administrators who do not appreciate the efforts of the teachers and do not support them reduced extrinsic motivation. Doğan and Koçak (2014) reported that there was a 
significant correlation between the social communication skills of administrators and teacher motivation. Özgan and Aslan (2008) concluded that the verbal communication style of the administrators affected the motivation of the teachers. According to Arslan (2012), there was a moderate, significant, and positive correlation between the democratic attitudes and behavior of school principals and teacher motivation. Sarı, Yıldız and Canoğulları (2018) reported that there was a low but significant correlation between the perceived principal administration style and teacher motivation, and the motivation levels of the teachers increased with the increase in school principal's cooperative management style level. Furthermore, it was concluded that teachers who worked with principals with authoritarian, indifferent, and opposing administration styles could exhibit occupational avoidance behavior.

The quantitative findings revealed a significant difference between the total motivation to teach and intrinsic motivation perceptions of the teachers based on their satisfaction with the attitudes and behavior of the parents towards the teachers. The total motivation to teach and intrinsic motivation perceptions of the teachers who were satisfied with the attitudes and behavior of the parents towards the teachers were higher than those who were not satisfied. This finding may suggest that satisfaction with parental attitudes and behavior towards the teachers affected the total motivation to teach and intrinsic motivation perceptions of the teachers. However, the effect was small. In the qualitative section of the study, it was stated by certain teachers that one of the factors that affected their motivation to teach was the parents. Parents' respect for teachers, their understanding and awareness and consciousness increased teachers' motivation to teach. Parents who were intrusive, disrespectful, indifferent, and unaware decreased their motivation to teach. Thus, the qualitative findings also determined that parental attitudes and behavior towards the teachers was a factor that affected teacher motivation. In this respect, it can be said that the result obtained in quantitative research was supported by qualitative research results. Similarly, Ada et al. (2013) demonstrated that parental interest, educating, non-prejudicial attitudes improved the extrinsic motivation of teachers, while disinterested, insensitive, uneducated, and inadequate parental behavior reduced the extrinsic motivation of teachers. According to Husny-Arar and MassryHerzlla (2016), parental indifference, lack of cooperation, conflict, and tensions between teachers and parents reduced teacher motivation.

The quantitative study findings revealed a significant difference between the total motivation to teach and intrinsic motivation perceptions of the teachers based on their satisfaction with the attitudes and behavior of the students towards the teachers favoring the satisfied teachers. There was also a significant difference between the total motivation to teach and intrinsic motivation and extrinsic motivation perceptions of the teachers based on their satisfaction with the attitudes and behavior of the students towards the course favoring the satisfied teachers. However, it was determined that these effects were small. On the other hand, in the qualitative section of the research, it was emphasized by the majority of teachers that one of the factors that affected teachers' motivation to teach was the students. Qualitative findings demonstrated that student attitudes and behavior towards the teachers and the course affected the teachers' motivation to teach. In this respect, it can be said that the result obtained in quantitative research was supported by qualitative research results. Students' academic interest and competence such as preparing for the class, possession of course material, asking questions, doing their homework, listening to the instruction, attendance, achievement, and readiness,. and their respect for teachers improved the motivation to teach. Students' academic disinterest and incompetence such as not caring about the course, reluctance towards the course, not listening to the instruction, being interested in other courses during the 
class, inadequate of readinessand their disrespect for the teacher, exhibition of undisciplined behavior that disrupt the instruction reduced the motivation to teach. Similarly, according to Ada et al. (2013), the student's readiness for the class and the student achievements increased the extrinsic motivation of the teachers, while insufficient student readiness, disinterest and failure reduced the extrinsic motivation. Börü (2018) reported that students' achievement levels, desire to learn and efficiency were among the variables that affected teacher motivation. According to Husny-Arar and Massry-Herzllah (2016), violent and undisciplined student behavior reduced teacher motivation. Bishay (1996), on the other hand, indicated that the motivation levels of the teachers were higher in schools with select students.

The quantitative study findings also determined that there was a significant difference between total motivation to teach and intrinsic motivation perceptions of the teachers based on their satisfaction with the attitudes and behavior of their colleagues towards the teachers. The total motivation to teach and intrinsic motivation perceptions of teachers who were satisfied with their colleagues' attitudes and behavior towards the teachers were higher than those who were not satisfied. This finding may suggest that the satisfaction with colleagues' attitudes and behavior towards the teachers affected the intrinsic motivation and total motivation to teach perceptions. However, it was determined that the effect was small. In the qualitative section of the study, it was determined that the work environment was one of the factors that affected teachers' motivation to teach. Based on the views in the theme of "work environment", psychological satisfaction (confidence, peace, satisfaction, happiness, sincerity, and so forth), cooperation, information exchange with field teachers and healthy communications improved teachers' motivation to teach. The lack of psychological satisfaction (insecurity, unhappiness, dissatisfaction, and the rest), lack of communication and negativity among colleagues decreased teachers' motivation to teach. However, only a few teachers mentioned these factors. Thus, qualitative findings also revealed that colleagues' attitudes and behavior towards the teachers were a factor that affected teacher motivation. In this respect, it can be said that the result obtained in quantitative research was supported by qualitative research results. Similarly, Ada et al. (2013) reported that positive human relations at school, solidarity among teachers, social activities with colleagues increased the extrinsic motivation of teachers, while insecurity, insincere human relationships, gossip and envy reduced the extrinsic motivation. Also according to Börü (2018), cooperation and solidarity among colleagues were among the factors that affected teacher motivation.

In the study, it was also observed that certain factors that were not discussed in the quantitative section affected the motivation of teachers to teach based on the qualitative data. The qualitative research findings revealed that government and work environment were among the factors that affected teachers' motivation to teach. The most frequently mentioned topics in government theme included the prestige of the teaching profession, the income level of the teachers and teacher autonomy. The improvement of the prestige of the teaching profession, the income level of teachers and teacher autonomy (independence in the use of methods and techniques in classes, removal of the pressures on teachers, and suchlike.) increased the motivation to teach, while the opposite reduced the motivation to teach according to the participants. On the work environment, the most frequently emphasized topic was the physical school conditions (tools, technological equipment, number of students, and the rest.). The adequacy of the physical school conditions increased the motivation of teachers to teach, while the opposite reduced the motivation to teach. Similarly, Ada et al. (2013) reported that economic well-being, adequate equipment and physical school facilities, and the availability of adequate classrooms increased the extrinsic motivation of teachers, while the lack of tools, crowded classes, and economic problems reduced the extrinsic motivation. 
Furthermore, it was reported that the decrease in the respect for the profession and feeling worthless reduced intrinsic motivation. Husny-Arar and Massry-Herzllah (2016) reported that crowded classes also played a role in reducing teacher motivation.

The general analysis of the study findings demonstrated that the attitudes and behavior of the school administrators, students, colleagues and parents towards the teacher and the attitudes and behavior of the students towards the course affected the teachers' motivation to teach based on the quantitative and qualitative findings. In this respect, quantitative research results in terms of these variables were supported by qualitative research results. These findings were expected. Because, teacher motivation is associated with how the teacher is treated and how the teacher perceives the living and working conditions (Davidson, 2007). On the other hand, the quantitative and qualitative personal variable findings were partially consistent. Based on both quantitative and qualitative findings, it was concluded that the marital status and professional seniority of the teachers did not affect their motivation to teach. However, quantitative and qualitative gender variable findings were not consistent. In this case, quantitative research results in terms of personal variables were partially supported by qualitative research results. While quantitative findings demonstrated that gender affected extrinsic motivation to teach, there was no qualitative evidence that gender affected motivation to teach. This may be due to the fact that teachers' intrinsic motivation perceptions are higher than their extrinsic motivation perceptions, while answering qualitative questions, they mostly offer opinions about intrinsic motivation factors. Thus, it could be suggested that the quantitative and qualitative study findings were mostly consistent.

Based on the study results, it could be recommended that school administrators should exhibit positive attitudes and behavior such as supporting the teachers, appreciating their work, exhibiting their trust, and understanding their needs to improve their motivation to teach. Regulations that would protect teachers and reflect the respect for teachers could help students and parents to exhibit positive attitudes and behavior towards the teachers, which in turn could improve teachers' motivation to teach. To increase the student interest in courses, the coefficient of the course could be increased in central exams, which in turn may improve teachers' motivation to teach. Creating a work environment where teachers could exchange information, communicate, and collaborate with each other could improve their motivation to teach.

\section{Note}

This study was presented as verbal presentation at VIth International Eurasian Educational Research Congress, June 19-22, 2019, Ankara-Turkey.

\section{References}

Ada, Ş., Akan, D., Ayık, A., Yıldırım, İ., \& Yalçın, S. (2013). Öğretmenlerin motivasyon etkenleri [Motivation factors of teachers]. Atatürk University Journal of Social Sciences Institute, 17(3), 151-166.

Akbaba, S. (2006). Eğitimde motivasyon [Motivation in education]. Journal of Kazım Karabekir Education Faculty, 13, 343-361.

Akman, Y. (2017). Öğretmenlerin algılarına göre iş motivasyonu ve örgütsel özdeşleşme arasındaki ilişki [The relationship between work motivation and organisational identification according to perceptions of teachers]. Journal of the Hasan Ali Yücel Faculty of Education, 14-1(27), 71-88. 
Alimohammadi, H., Sohrabi, M., \& Saberi, A. (2017). The relationship between motivation to teach and teaching method of Physical educators. Journal of Advanced Pharmacy Education \& Research, 7(4), 515-523. Retrieved from https://www.researchgate.net/profile/Alireza_Saberi_Kakhki/publication/326545459_ The_relationship_between_motivation_to_teach_and_teaching_method_of_physical_e ducators/links/5beac0ee299bf1124fce7583/The-relationship-between-motivation-toteach-and-teaching-method-of-physical-educators.pdf.

Altay, G. B. (2019). Müzik ögretmenlerinin mesleki memnuniyet ve ögretme motivasyonlarl (Konya ili örneği) [Professional pleasure and teaching motivation of music teachers (Example of Konya province)]. (Unpublished master's thesis). Necmettin Erbakan University Institute of Educational Sciences, Konya.

Amin, M. (2015). Relationship between job satisfaction, working conditions, motivation of teachers to teach and job performance of teachers in MTs, Serang, Banten. Journal of Management and Sustainability, 5(3), 141-154. doi:10.5539/jms.v5n3p141.

Argon, T., \& Cicioğlu, M. (2017). Meslek lisesi öğretmenlerinin eğitime inanma düzeyleri ile öğretme motivasyonları [Vocational high school teachers' levels of belief in education and motivation to teach]. The Journal of Academic Social Science Studies, 57, 1-23. doi: $10.9761 / \mathrm{JASSS7108.}$

Arslan, M. C. (2012). İlkögrretim okul müdürlerinin demokratik tutum ve davranışlarının ögretmen motivasyonu ve ögrenci başarlsina etkisi [The effect of primary school principals of democratic attitudes and behaviors on teacher motivation and student performance]. (Unpublished master's thesis). Gaziantep University, Institute of Social Sciences, Gaziantep.

Atkinson, E. S. (2000) An investigation into the relationship between teacher motivation and pupil motivation. Educational Psychology, 20(1), 45-57. doi: 10.1080/014434100110371.

Avcı, O. (2019). Beden ĕgitimi ve spor öğretmenleri ile diğer branş ögretmenlerinde öğretme motivasyonu ve ögretmen öz yeterlilikleri arasindaki ilişkinin incelenmesi [Studying the relation between teaching motivation and teaching self-competence of physical education and sports teachers, and branch teachers]. (Unpublished master's thesis). Muğla Sitkı Koçman University, Institute of Health Sciences, Muğla.

Ayık, A., Ataş-Akdemir, Ö., \& Seçer, İ. (2015). Öğretme motivasyonu ölçeğinin Türkçe'ye uyarlanması: Geçerlik ve güvenirlik çalışması [Adaptation of the motivation to teach scale into Turkish: The validity and reliability study]. Current Research in Education, 1(1), 33-45.

Barbieri, G., Rossetti, C., \& Sestito, P. (2017). Teacher motivation and student learning. Politica Economica, 33(1), 59-72.

Bishay, A. (1996). Teacher motivation and job satisfaction: A study employing the experience sampling method. Journal of Undergraduate Sciences, 3, 147-154.

Börü, N. (2018). The factors affecting teacher motivation. International Journal of Instruction, 11(4), 761-776.

Büyüköztürk, Ş. (2012). Sosyal bilimler için veri analizi el kitabı: İstatistik, araştırma deseni ve Spss uygulamalarl [Data analysis handbook for social sciences: Statistics, research design and Spss applications]. Ankara: Pegem Akademi.

Büyüköztürk, Ş., Kılıç-Çakmak, E., Akgün, Ö. E., Karadeniz, Ş., \& Demirel, F. (2016). Bilimsel araştırma yöntemleri. [Scientific research methods ]. Ankara: Pegem Akademi.

Creswell, J. W. (2014). Research design: Qualitative, quantitative and mixed methods approaches. Thousand Oaks, California: Sage. 
Creswell, J. W., \& Plano Clark, V. L. (2015). Karma yöntem araştırmaları: Tasarımı ve yürütülmesi [Mixed method research: Design and execution]. Ankara: An1.

Czubaj, C. A. (1996). Maintaining teacher motivation. Education, 116(3), 372-378.

Davidson, E. (2007). The pivotal role of teacher motivation in Tanzanian education. The Educational Forum, 71(2), 157-166.

Dobre, O. (2013). Employee motivation and organizational performance. Review of Applied Socio- Economic Research, 5(1), 53-60.

Doğan, S., \& Koçak, O. (2014). Okul yöneticilerinin sosyal iletişim becerileri ile öğretmenlerin motivasyon düzeyleri arasındaki ilişki [Relationship between school administrators' social communication skills and teachers' motivation]. Educational Administration: Theory and Practice, 20(2), 191-216. doi: 10.14527/kuey.2014.009

Doğan, Y., \& Koçak, O . (2017). Ortaokullarda görev yapan öğretmenlerin öğretmen motivasyonuna ilişkin algı ve görüşleri [Perceptions and views of teachers who work in middle schools regarding teacher motivation]. Anadolu University Journal of Social Sciences, 17 (1), 1-18.

Dörnyei, Z., \& Ushioda, E. (2011). Teaching and researching motivation. Harlow: Longman.

Emiroğlu, O. (2017). Öğretmen motivasyon kaynaklarına ilişkin okul yöneticisi ve ögrretmen görüssleri [School administrators and teachers opinions about the motivational source of teachers]. (Unpublished doctoral dissertation). Near East University, Institute of Educational Sciences, Lefkoşa.

Ertürk, R. (2016). Öğretmenlerin iş motivasyonları [Work motıvatıon of teachers]. Journal of Education, Theory and Practical Research, 2(3), 1-15.

Ertürk, R., \& Aydın, B. (2017). Öğretmenlerin iş motivasyonunu arttıran ve olumsuz etkileyen durumlarin incelenmesi [Investigation of the situations that increase the motivation of the teachers and negatively affect them]. The Journal of Academic Social Science, 58, 582-603.

Evans, L. (1998). Teacher morale, job satisfaction and motivation. London: Paul Chapman.

Han, J., \& Yin, H. (2016). Teacher motivation: Definition, research development and implications for teachers. Cogent Education, 3(1217819), 1-18. doi: 10.1080/2331186X.2016.1217819.

Hein, V., Ries, F., Pires, F., Caune, A., Emeljanovas, A., Ekler, J. H., \& Valantiniene, I. (2012). The relationship between teaching styles and motivation to teach among physical education teachers. Journal of Sports Science and Medicine, 11, 123-130.

Husny-Arar, K., \& Massry-Herzllah, A. (2016). Motivation to teach: the case of Arab teachers in Israel. Educational Studies, 42(1), 19-35. doi: 10.1080/03055698.2015.1127136.

Iliya, A., \& Ifeoma, L. G. (2015). Assessment of teacher motivation approaches in the less developed countries. Journal of Education and Practice, 6(22), 10-17.

İlğan, A., Canoğlu,Ö., Karamert, Ö., \& Şensoy, Ç. P. (2018). Öğretmenlerin çocuk sevme düzeyleri ile öğretme motivasyonları arasındaki ilişkinin incelenmesi [Examining relationship between like of children level and teaching motivation of teachers]. Turkish Studies Educational Sciences, 13(19), 979-1003. doi: 10.7827/TurkishStudies.13985.

Katıtaş, S. (2019). Karma yöntem araştırmalarına bütüncül bir bakış [A holistic overview of the mixed method research]. International Social Sciences Studies Journal, 5(49), 6250-6260. doi: 10.26449/sssj.1858.

Kauffman, D. F., Y1lmaz-Soylu, M., \& Duke, B. (2011). Validation of the motivation to teach scale. Hacettepe University Journal of Education, 40, 279-290. 
McInerney, D. M., \& Liem, A. D. (2008). Motivation theory and engaged learning. (pp.1136.) In P.A. Towndrow, C. Koh and T.H. Soon (Eds.), Motivation and Practice for the Classroom. Rotterdam: Sense Publishers.

Nadim, M., Chaudhry, M. S., Kalyar, M. N., \& Riaz, T. (2012). Effects of motivational factors on teachers' job satisfaction: A study on public sector degree colleges of Punjab, Pakistan. The Journal of Commerce, 4(4), 25-32.

Ofoegbu, F. I. (2004). Teacher motivation: A factor for classroom effectiveness and school improvement in Nigeria. College Student Journal, 38(1), 81-89.

Özdemir, T. Y., Kartal, S. E., \& Yirci, R. (2014). Okul müdürlerinin öğretmenleri motive etme yaklaşımları [School principals' approaches to motivate teachers]. Turkish Journal of Educational Studies, 1(2), 190-215.

Özgan, H., \& Aslan, N. (2008). İlköğretim okul müdürlerinin sözlü iletişim biçiminin ögrretmenlerin motivasyonuna etkisinin incelenmesi [Analysis of the effect of secondary school principles' verbal communication styles on teachers' motivation]. Gaziantep University Journal of Social Sciences, 7(1), 190-206.

Pallant, J. (2017). Spss kullanma kulavuzu: Spss ile adım adım veri analizi [Spss user guide: Step-by-step data analysis with Spss]. (S. Balc1 ve B. Ahi Trans.). Ankara: Anı publishing.

Retelsdorf, J., Butler, R., Streblow, L., \& Schiefele, U. (2010). Teachers' goal orientations for teaching: Associations with instructional practices, interest in teaching, and burnout. Learning and Instruction, 20(1), 30-46. doi:10.1016/j.learninstruc.2009.01.001

Ryan, R. M., \& Deci, E. L. (2000). Intrinsic and extrinsic motivations: Classic definitions and new directions. Contemporary Educational Psychology, 25, 54-67. doi:10.1006/ceps.1999.1020.

Sarı, M., Canoğulları, E., \& Yıldız, E. (2018a). Öğretmenlerin okul yaşam kalitesi algıları ile mesleki motivasyon düzeylerinin incelenmesi [An investigation of teachers' professional motivation levels and quality of school life perceptions]. Mehmet Akif Ersoy University Journal of Education Faculty, 47, 387-409. doi: 10.21764/maeuefd.364454

Sarı, M , Yıldız, E., \& Canoğulları, E . (2018b). Öğretmenlerin algıladıkları müdür yönetim tarzı ile mesleki motivasyon düzeylerinin incelenmesi [An investigation of teachers' perceived principal management style and professional motivation levels]. International Journal of Social and Educational Sciences, 5 (10), 188-208. doi: 10.20860/ijoses.467606.

Seçer, İ. (2017). SPSS ve LISREL ile pratik veri analizi: Analiz ve raporlaştırma. [Practical data analysis with SPSS and LISREL: Analysis and reporting].Ankara: An1.

Sinclair, C. (2008). How can what we know about motivation to teach improve the quality of initial teacher education and its practicum? (pp. 37-61). In P.A. Towndrow, C. Koh and T.H. Soon (Eds.), Motivation and Practice for the Classroom, The Netherlands: Sense Publishers.

Şad, S. N., \& Şahiner, Y. K. (2016). Temel eğitimden ortaöğretime geçiş (TEOG) sistemine ilişkin öğrenci, öğretmen ve veli görüşleri [Students' teachers' and parents' views about transition from basic education to secondary education (BESE) system]. Elementary Education Online, 15(1), 53-76. doi: 10.17051/io.2016.78720.

Tanrı̈̈̆gen, A. (2018). Örgütlerde etkili insan ilişkileri [Effective human relations in organizations]. Ankara: Anı Publishing.

Tulunay-Ateş, Ö., \& Buluç, B. (2018). İlköğretim öğretmenlerinde motivasyon ve örgütsel bağlılığın demografik değişkenler açısından incelenmesi [Examining motivation and organizational commitment in primary education teachers in terms of demographic 
variables]. Mehmet Akif Ersoy University Journal of Education Faculty, 48, 1-30. doi: 10.21764/maeuefd.420320

Yazıcı, H. (2009). Öğretmenlik mesleği, motivasyon kaynakları ve temel tutumlar: Kuramsal bir bakış [Teaching profession sources of motivation and basic attitudes: A Theoretical overview]. Kastamonu Education Journal, 17(1), 33-46.

Yıldırım, A., \& Şimşek, H. (2011). Sosyal bilimlerde nitel araştırma yöntemleri [Qualitative research methods in the social sciences]. Ankara: Seçkin publishing.

Yılmaz, M. (2014). Ortaokul ögretmenlerinin güdülenme ve iş doyumu düzeyleri arasındaki ilişki [The relationship between motivation and job satisfaction levels of secondary school teachers]. (Unpublished master's thesis). Adnan Menderes University, Institute of Social Sciences, Aydin.

Watters, J. J., \& Ginns, I. S. (2000). Developing motivation to teach elementary science: Effect of collaborative and authentic learning practices in preservice education. Journal of Science Teacher Education, 11(4), 301-321. doi: 10.1023/A:1009429131064.

Webb, R. B., \& Ashton, P. T. (1986). Teacher motivation and the conditions of teaching: A call for ecological reform. Journal of Thought, 21(2), 43-60. 